\title{
Application of surface plasmon resonance of citrate capped silver nanoparticles for the selective determination of some fluoroquinolone drugs
}

\author{
Sayed M. Derayea ${ }^{\mathrm{a}}$, Mahmoud A. Omar ${ }^{\mathrm{a}}$, Mohamed A. Hammad ${ }^{\mathrm{a}}$, Yasser F. Hassan ${ }^{\mathrm{b}}$ \\ ${ }^{a}$ Department of Analytical Chemistry, Faculty of Pharmacy, Minia University, Minia 61519, Egypt. \\ ${ }^{b}$ Department of Pharmaceutical Analytical Chemistry, Faculty of Pharmacy, Al-Azhar University, Assiut branch, Assiut 71524, Egypt.
}

\begin{tabular}{|c|c|}
\hline ARTICLE INFO & ABSTRACT \\
\hline $\begin{array}{l}\text { Article history: } \\
\text { Received on: } 15 / 10 / 2016 \\
\text { Accepted on: 07/11/2016 } \\
\text { Available online: } 27 / 02 / 2017\end{array}$ & $\begin{array}{l}\text { Citrate capped silver nanoparticles (Ag NPs) was used as a colorimetric probe for the sensitive determination of } \\
\text { six drugs belongs to fluoroquinolone family (Ciprofloxacin, Lomefloxacin, Ofloxacin, Pefloxacin, Levofloxacin } \\
\text { and Moxifloxacin). The interaction between the studied fluoroquinolones and citrate-capped Ag NPs resulted in } \\
\text { the appearance of new surface plasmon resonance (SPR) peaks measured in the range of } 598-696 \mathrm{~nm} \text {. Under } \\
\text { the optimized conditions, good linear relationships }\left(\mathrm{R}^{2}=0.9973-0.9991\right) \text { were obtained in the range of } 1.50-\end{array}$ \\
\hline $\begin{array}{l}\text { Key words: } \\
\text { Surface plasmon resonance } \\
\text { spectroscopy; } \\
\text { Fluoroquinolones; } \\
\text { Silver nanoparticles; } \\
\text { Pharmaceutical analysis. }\end{array}$ & $\begin{array}{l}10.25,2.0-10.25,2.0-10.50,2.0-10.50,1.5-10.0 \text { and } 2.0-11.0 \mu \mathrm{g} / \mathrm{mL} \text { for Ciprofloxacin, Ofloxacin, } \\
\text { Levofloxacin, Moxifloxacin, Lomefloxacin and Pefloxacin, respectively. The analytical performance of the } \\
\text { method was fully validated, and the results were satisfactory. Different pharmaceutical dosage forms containing } \\
\text { the cited drugs were successfully analyzed by the suggested method with high degree of accuracy and precision. } \\
\text { The proposed method is environmentally safe as it use water as a solvent and does not involve solvent } \\
\text { extraction. }\end{array}$ \\
\hline
\end{tabular}

\section{INTRODUCTION}

Quinolones are a class of broad-spectrum antibiotics, which are active against both gram-positive and gram-negative bacteria. The parent compound of all fluoroquinolones is nalidixic acid. Fluoroquinolones are quinolones derivatives bearing a fluorine atom in the C-6 position. Which has made considerable progress in expanding their spectrum of activity (Kaur et al., 2008). Quinolones rapidly inhibit DNA synthesis by promoting cleavage of bacterial DNA in the DNA-enzyme complexes of DNA gyrase and type IV topoisomerase, resulting

\footnotetext{
* Corresponding Author

Yasser Hassan, Department of Pharmaceutical Analytical Chemistry, Faculty of Pharmacy, Al-Azhar University, Assiut branch, Assiut 71524, Egypt. Email: yasseralkady272 @ yahoo.com
}

in rapid bacterial death (Hooperand Wolfson 1993, Mandell et al., 2000). In the present work, six fluoroquinolone drugs namely; Ciprofloxacin, Lomefloxacin, Ofloxacin, Pefloxacin, Levofloxacin and Moxifloxacin were investigated (Fig. 1).

Many analytical methods were found in literature for detection and determination of the studied antibacterial drugs in bulk, pharmaceutical formulations, and/or in biological fluids. The USP(Rockville 2000) recommends a liquid chromatographic method for determination of ciprofloxacin. A non-aqueous titrimetric method was recommended for ciprofloxacin in USP, Ofloxacin in the BP (Pharmacopoeia, 1998) and Pefloxacin mesylate dihydrate in the European Pharmacopoeia (E.P) (Pharmacopoeia, 1998). The other studied drugs are not official in either pharmacopoeia. Non official methods reported for the determination of the studied drugs included titrimetric (Kiliç et al., 1994; Zhang etal., 1996), spectrophotometric 
<smiles>O=C(O)c1cn(C2CC2)c2cc(N3CCNCC3)c(F)cc2c1=O</smiles>

Ciprofloxacin<smiles>CCn1cc(C(=O)O)c(=O)c2cc(F)c(N3CCN(C)CC3)cc21</smiles>

Pefloxacin

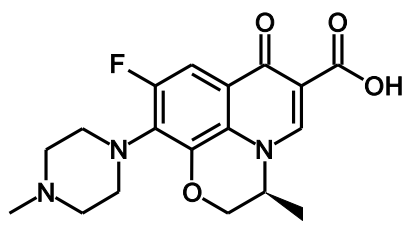

Levofloxacin

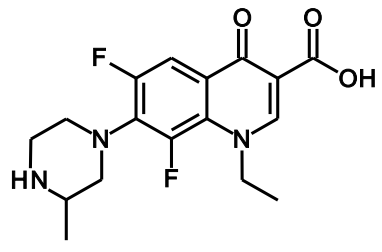

Moxifloxacin<smiles>C[C@H]1COc2c(N3CCN(C)CC3)c(F)cc3c(=O)c(C(=O)O)cn1c23</smiles>

Ofloxacin<smiles>COc1c(N2CC3CCCNC3C2)c(F)cc2c(=O)c(C(=O)O)cn(C3CC3)c12</smiles>

Lomefloxacin

Fig. 1: Chemical structures of the investigated fluoroquinolones.

(Fratiniand Schapoval, 1996; Abdel-Gawad et al., 1998; Rajasekaran et al., 1998; Basavaiahand Prameela, 2002; El-Brashy et al., 2004; El- Brashy et al., 2005; Al- Momani, 2006; Sultan, 2009; Siddiqui et al., 2010; Jain et al., 2011; Ayad et al., 2012; ElHawaryand Al-Gethami, 2012; Tarkase et al., 2012), Spectrofluorimetric (Jelikić-Stankov et al., 1999; Navalón et al., 2000; Rizk et al., 2000; El-Kommos et al., 2003; Salem, 2005; Kaur et al., 2010; Shah et al., 2013), electrochemical (Belaland ElDin, 1990; Tamer, 1990; Avsecand Gomišček, 1992; Ni et al., 2006), IR (Parent et al., 2004), NMR (Sakai et al., 1999), separation techniques (Wang et al., 1997; Schenckand Callery, 1998; Fierens et al., 2000; González et al., 2005; Gupta et al., 2010; Sousa et al., 2012). Recently, noble metal nanoparticlesbased UV-visible spectrometric methods have drawn special attention for selective and sensitive reorganization of target species (inorganic, organic and biomolecules) in various complex matrices (Vilela et al., 2012).

Since, metallic NPs (Au and Ag NPs) are emerging as promising analytical colorimetric reporters for wide variety of analytes because of their intrinsically exploitable properties such as the high extinction coefficient and the distinct variation in color based on their dispersion and aggregation state (Willetsand Van Duyne, 2007; Jain et al., 2008). As a result, noble metallic NPs have been used as promising coloring probes for selective, on-site and real-time colorimetric sensing of a wide variety molecules from various matrices, which facilitates to visualize targets species directly with naked eye (Jain, Huang et al. 2008). Recent years, Ag NPs-based signal amplifications hold great promise in the development of sensitive and selective miniaturized UV-visible approaches for real-time monitoring of trace level target species in complex samples (Ravindran et al., 2013).

For example, Ag NPs are functionalized with various organic derivatives and were used as colorimetric probe for determination of various organic molecules (pesticides, amino acids and DNA) (Thompson et al., 2008; Xiong et al., 2008; Xiongand Li, 2008). Herein, to enhance the sensitivity and selectivity for fluroquinolones determination, we demonstrate the potential use of citrate-capped AgNPs as colorimetric sensor for these drugs. The method is based on the aggregation of citratecapped Ag NPs induced by the studied drugs.

\section{EXPERIMENTAL}

\section{Materials and Reagents}

All reagents used were of analytical grade and were used without further purification.

Pharmaceutical grade ciprofloxacin hydrochloride was supplied by Kahira Pharmaceuticals \& Chemical Industries Company (Cairo, Egypt). Ofloxacin powder was kindly supplied by the Egyptian International Pharmaceutical Industries Company (EIPICO, Cairo, Egypt), Moxifloxacin hydrochloride was obtained from EVA Pharm. \& Chem. Ind. Company (Cairo, Egypt) and Medical Union Pharmaceuticals (MUP, Cairo, Egypt). Levofloxacin hydrochloride was obtained from Memphis Pharmaceuticals \& Chemical Industries Co. (Cairo, Egypt). Lomefloxacin hydrochloride by Sigma pharmaceutical Industries (El-Menoufia, Egypt) and Pefloxacin was supplied by Global Napi pharmaceuticals Company, (6 ${ }^{\text {th }}$ October City, Egypt). Silver nitrate was obtained from Sigma-Aldrich, sodium borohydride $\left(\mathrm{NaBH}_{4}\right)$ and sodium citrate from Merck (Germany).

Toerell \& Stenhagen buffer solution was prepared by mixing the aqueous solutions of; phosphoric acid $(3.5 \mathrm{~mL} / 100$ $\mathrm{mL}$, El-Nasr chemical company, Cairo, Egypt), citric acid (7 g/100 $\mathrm{mL}$, United company for Chem. \& Med. Prep., Cairo, Egypt) and sodium hydroxide $(4 \mathrm{~g} / 100 \mathrm{~mL}$, Isochem specifications, Cairo, Egypt). The volume was completed to $1000 \mathrm{~mL}$ with distilled water to give buffer stock solution. An appropriate volume from the stock solution was adjusted to the required $\mathrm{pH}$ with $0.1 \mathrm{M}$ hydrochloric acid (36\%, Lab-Chem fine chemicals \& reagents, Cairo, Egypt).

\section{Pharmaceutical formulations}

All pharmaceutical preparations were purchased from the local market. Ciprofloxacin tablet: (Amriya Pharm. Ind., 
Alexandria, Egypt) labeled to contain $500 \mathrm{mg}$ Ciprofloxacin per tablet. Venaxan tablet: (SEDICO Pharmaceutical Company, Giza, Egypt) labeled to contain $500 \mathrm{mg}$ Levofloxacin per tablet. Moxacin tablet: (Medical Union Pharmaceuticals MUP, Cairo, Egypt) labeled to contain $400 \mathrm{mg}$ Moxifloxacin per tablet. Maxaflox tablets: (Pharaonia Pharmaceuticals Company, Alexandria, Egypt) labeled to contain $400 \mathrm{mg}$ Lomefloxacin per tablet. Globacin tablet: (Global Napi pharmaceuticals Company, $6^{\text {th }}$ October city, Egypt) labeled to contain $400 \mathrm{mg}$ Pefloxacin per tablet. Ofloxin tablets: (Kahira Pharmaceuticals \& Chemical Industries Company, Cairo, Egypt) labelled to contain $200 \mathrm{mg}$ Ofloxacin per tablet.

Ciprocin eye drop: (the Egyptian International Pharmaceutical Industries Company EIPICO, Cairo, Egypt) labeled to contain $3 \mathrm{mg}$ Ciprofloxacin per $1 \mathrm{ml}$ solution. Maxaflox eye drop: (Pharaonia Pharmaceuticals Company, Alexandria, Egypt) labeled to contain $3 \mathrm{mg}$ Lomefloxacin per $1 \mathrm{ml}$ solution. Vigamox eye drop: (Alcon, Giza, Egypt) labeled to contain $3 \mathrm{mg}$ Moxifloxacin per $1 \mathrm{ml}$ solution. Ofloxin eye drop: (Kahira Pharmaceuticals \& Chemical Industries Company, Cairo, Egypt) labeled to contain $3 \mathrm{mg}$ Ofloxacin per $1 \mathrm{ml}$ solution. Lee-flox eye drop: (SEDICO Pharmaceutical Company, Giza, Egypt) labeled to contain $5 \mathrm{mg}$ Levofloxacin per $1 \mathrm{ml}$ solution. Ciprofloxacin injection for intravenous infusion: (Amriya Pharm. Ind., Alexandria, Egypt) labeled to contain $200 \mathrm{mg}$ ciprofloxacin lactate monohydrate per $100 \mathrm{ml}$ infusion solution. Venaxan injection for intravenous infusion: (SEDICO Pharmaceutical Company, Giza, Egypt) labeled to contain $500 \mathrm{mg}$ Levofloxacin per $100 \mathrm{ml}$ of solution for infusion.

\section{Instrumentation}

UV-visible spectra were measured by using Shimadzu UV-1601PC UV-Visible, Scanning Spectrophotometer Detector: Silicon photodiode. All weighing were performed on an electronic single pan balance (Precisa XB 220A, Switzerland)). Distilled water was prepared by water distiller (TYUMEN-MIDI-A0-25 MO, Russia). Boeco magnetic stirrer mms 300012 V. 300 mA 03000 1/min (Germany) and pH-meter, model AD11P (Adwa, Romania) were used.

\section{Procedures}

\section{Preparation of standard solution}

Stock solutions containing $300 \mu \mathrm{g} / \mathrm{mL}$ of each fluoroquinolone were prepared in distilled water; Working standard solutions of the appropriate concentrations were prepared by suitable dilution of the stock solutions with distilled water.

\section{Preparation of pharmaceutical samples}

Tablets

An accurately weighed amount, equivalent to $12 \mathrm{mg}$ of each drug from composite of 20 powdered tablets, was transferred into a $100-\mathrm{mL}$ calibrated flask and sonicated with about $50 \mathrm{~mL}$ of distilled water for $20 \mathrm{~min}$. The solution was diluted to the mark with distilled water and filtered off. further dilutions were made to obtain sample solutions of the required concentrations .

Eye drops and I.V infusion

Specific volumes of drops or I.V. infusion solutions equivalent to $3 \mathrm{mg}$ pure drug were placed in $25 \mathrm{ml}$ volumetric flask and diluted to $25 \mathrm{ml}$ with distilled water. Further dilutions were made to obtain sample solutions of the required concentrations.

\section{Preparation and Characterization of Silver Nanoparticles}

Citrate-capped Ag NPs were prepared by the reduction of $\mathrm{AgNO}_{3}$ with $\mathrm{NaBH}_{4}$ as a reducing agent and sodium citrate as a stabilizer, according to the method in the literature (Guo et al., 2008). Briefly, $25 \mathrm{~mL}$ of $\mathrm{AgNO}_{3}(2.5 \mathrm{mM}$ ) was added drop wise to $70 \mathrm{~mL}$ of a freshly prepared aqueous solution of $\mathrm{NaBH}_{4}(2.5 \mathrm{mM})$ with vigorous stirring.

After $10 \mathrm{~min}, 5 \mathrm{~mL}$ of sodium citrate solution $(1.25 \%$ w/w) was added to stabilize the AgNPs formed. The yellow colloidal solution of Ag NPs was then stirred for another $20 \mathrm{~min}$ and aged for 2 days at $4{ }^{\circ} \mathrm{C}$ before use. Reaction conditions including stirring time and relative quantities of reagents must be carefully controlled to obtain stable yellow colloidal silver.

If stirring was continued once all of the silver nitrate was added, aggregation began as the yellow solution first turned to darker yellow then violet and eventually grayish after which the colloid broke down and particle settled out.

\section{General Analytical Procedure}

A volume of $1 \mathrm{ml}$ of the drug standard or sample solution in the concentration range of $10-110 \mu \mathrm{g} / \mathrm{mL}, 1 \mathrm{~mL}$ of $0.25 \mathrm{mM}$ prepared AgNPs solution and $1 \mathrm{~mL}$ of Toerell \& Stenhagen buffer solution ( $\mathrm{pH} 8$ for Ofloxacin, Pefloxacin and Levofloxacin and $\mathrm{pH}$ 9 for Ciprofloxacin, Lomefloxacin and Moxifloxacin) were added, mixed thoroughly, and allowed to stand for $5 \mathrm{~min}$. The volume was completed to $10 \mathrm{~mL}$ with distilled water and the absorbance of the resultant solution was measured at 598, 598, 630, 648, 648 and $696 \mathrm{~nm}$ for Ofloxacin, Levofloxacin, Moxifloxacin, Ciprofloxacin, Lomefloxacin and Pefloxacin, respectively. Reagent blank was treated in the same manner replacing the drug with distilled water.

\section{RESULTS AND DISCUSSION}

After reduction of $\mathrm{Ag}^{+}$ions with sodium borohydride as a reducing agent in the presence of sodium citrate, the solution appeared bright yellow which has a maximum absorption at 397 $\mathrm{nm}$ and was attributed to the SPR of monodispersed AgNPs (Qu et al., 2012). This was due to a negative electro-static layer caused by citrate caps on AgNPs, forcing each particle to remain separate of neighboring particles. From the literature (Laliwala et al., 2014), a positively charged molecule can effectively trigger citrate capped nanoparticles to aggregate. Accordingly, fluoroquinolones group can also induce particle aggregation if it has a net positive charge. 
Under this assumption, positively charged fluoroquinolones were formed and subsequently interacted with AgNPs.

The dramatic changes of the absorption spectra and solution color of citrate-capped Ag NPs on exposure to six fluoroquinolone drugs (Fig. 2) confirmed that the aggregation mechanism of AgNPs was caused by electrostatic interaction between negatively charged citrate stabilized particle surfaces and the positive charges of fluoroquinolone drug.

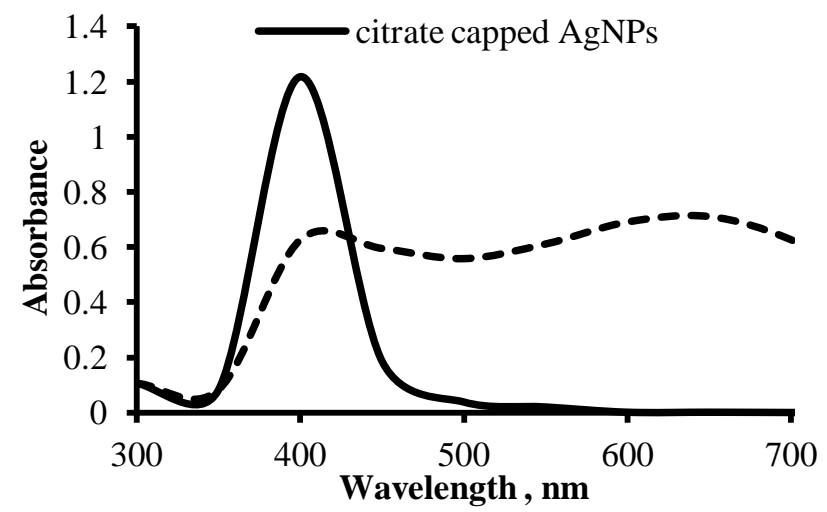

Fig. 2: The absorption spectra of citrate-capped Ag NPs (-) and its reaction product with Ciprofloxacin (- - ).

\section{Optimization of Reaction Conditions}

AgNPs have their own unique band, which strongly depends on size, shape, inter-particle distance and the surrounding medium. factors facilitating the SPR change in a presence of target analyte were critically studied.

\section{Effect of Silver nitrate concentration}

In this work, the as-prepared AgNPs concentration (calculated based on the final concentration of $\mathrm{AgNO}_{3}$ ) was 0.25 $\mathrm{mM}$. Suspension of $0.5 \mathrm{mM}$ AgNPs was diluted to $0.05-0.5 \mathrm{mM}$ prior to reaction with studied drugs. The result showed that 0.25 mM AgNPs promoted maximum absorbance and better sensitivity, so this concentration was chosen for the assay procedure (supplementary data, SI 1).

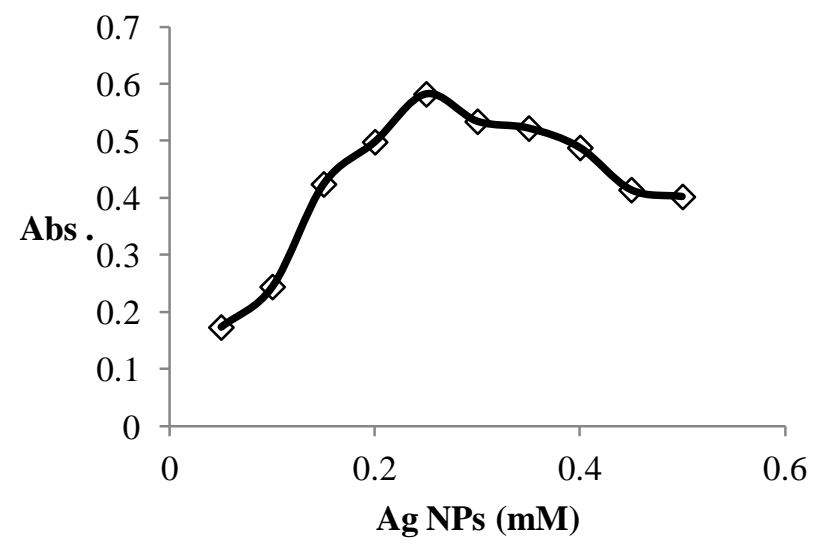

SI 1: The effect of concentration of AgNPs on the SPR absorbance of the reaction between $1 \mathrm{ml}$ of AgNPs $(0.05-0.5 \mathrm{Mm})$ and $1 \mathrm{ml}$ of $7 \mu \mathrm{g} / \mathrm{ml}$ Lomefloxacin (as an example) in the presence of $1 \mathrm{ml}$ of Toerell \& Stenhagen buffer solution ( $\mathrm{pH} 9)$.

\section{Effect of pH}

The $\mathrm{pH}$ of media did not only influenced the electrical charge of target analyte, but also affect the particle stability(Patel et al., 2015). There is well established study on the agglomeration of metallic NPs surfaces at low $\mathrm{pH}(<4)$, which explains the neutralization of NPs surface charges (aggregation), and resulting a change in their SPR band without addition of analytes(Basu et al., 2007). In order to investigate the best $\mathrm{pH}$ for effective colorimetric sensing of fluoroquinolone drugs with citrate-capped Ag NPs, we studied the UV-visible absorption spectra of citratecapped Ag NPs after the addition of studied drugs at different $\mathrm{pH}$ ranges from 4 to 10 (Fig. 3).

Based on the obtained results, we selected $\mathrm{pH} 8$ for Ofloxacin, Pefloxacin and Levofloxacin and $\mathrm{pH} 9$ for Ciprofloxacin, Lomefloxacin and Moxifloxacin as the optimum $\mathrm{pH}$ which gave the maximum absorbance and reproducible results. Since, citrate molecules on surfaces of Ag NPs exhibit negative charges, while amino groups of fluoroquinolone drugs bear positive charge, and yielding strong electrostatic interactions between surfaces of Ag NPs and fluoroquinolone drugs, which allow Ag NPs aggregation. As a result, the SPR band at $397 \mathrm{~nm}$ was red-shift, and resulting new SPR bands.

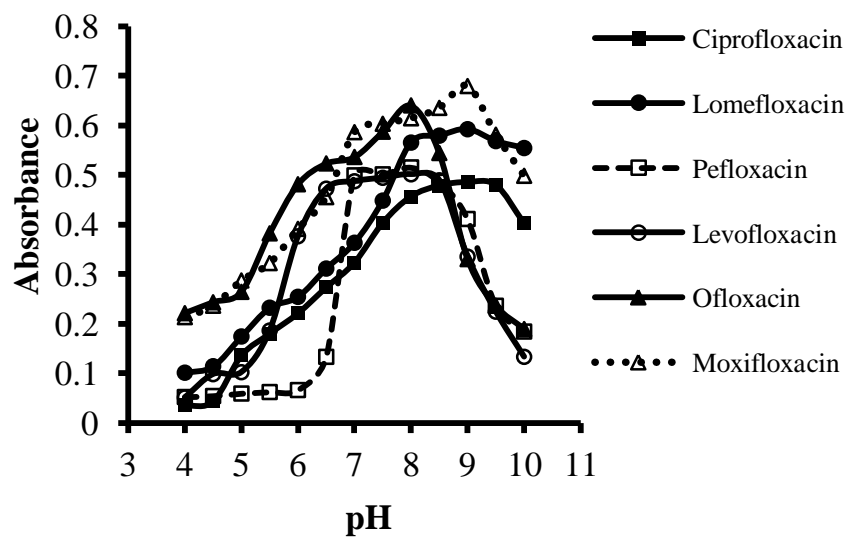

Fig. 3: Effect of $\mathrm{pH}$ on the SPR absorbance of the reaction product between 1 $\mathrm{ml}$ of AgNPs $(0.25 \mathrm{Mm})$ and $1 \mathrm{ml}$ of $7 \mu \mathrm{g} / \mathrm{ml}$ of fluoroquinolone drugs in the presence of $1 \mathrm{ml}$ of Toerell \& Stenhagen buffer solution $\mathrm{pH}$ (4-10).

\section{Effect of buffer type and volume}

Different types of buffers were used to adjust the $\mathrm{pH}$ of the media and their effect on the SPR absorbance of the corresponding reaction was examined.. For example, in the case of Lomefloxacin $(7 \mu \mathrm{g} / \mathrm{mL})$ the obtained absorbance values were $0.272,0.439,0.253,0.204$, and 0.586 for phosphate, BrittonRobinson, borate, carbonate and Toerell \& Stenhagen buffers, respectively. As the best results was obtained using Toerell \& Stenhagen buffer, it was chosen for subsequent study.

The effect of buffer volume on the SPR absorbance of the corresponding reaction was also studied over the volume range 0.2-2.0 $\mathrm{mL}$ of Toerell \& Stenhagen buffer solution. It was found that $1.0 \mathrm{~mL}$ promoted maximum absorbance and better sensitivity (supplementary data, SI 2). 


\section{Effect of reducing agent type and concentration}

In general, different reducing agents such as ascorbate, $\mathrm{NaBH}_{4}$, elemental hydrogen, polyol process, Tollens reagent and $\mathrm{N}, \mathrm{N}$-dimethylformamide (DMF) are used for reduction of silver ions $\left(\mathrm{Ag}^{+)}\right.$in aqueous or non-aqueous solutions. The aforementioned reducing agents reduce silver ions $\left(\mathrm{Ag}^{+}\right)$and lead to the formation of metallic silver $\left(\mathrm{Ag}^{\circ}\right)$, which is followed by agglomeration into oligomeric clusters. These clusters eventually lead to formation of metallic colloidal silver particles (Evanoffand Chumanov 2004, Merga et al., 2007). In case of using $\mathrm{NaBH}_{4}$, as reducing agent, preparation of uniform and size controllable nanoparticles was promoted (Leeand Meisel 1982). Solutions of nanoparticles with various concentrations of $\mathrm{NaBH}_{4}$ were examined. The maximum absorbance of AgNPs at $397 \mathrm{~nm}$ was observed in the presence of $2.5 \mathrm{mM} \mathrm{NaBH} 4$ solution (supplementary data, SI 3). Thus the synthesis of nanoparticles was done using this amount of $\mathrm{NaBH}_{4}$ solution.

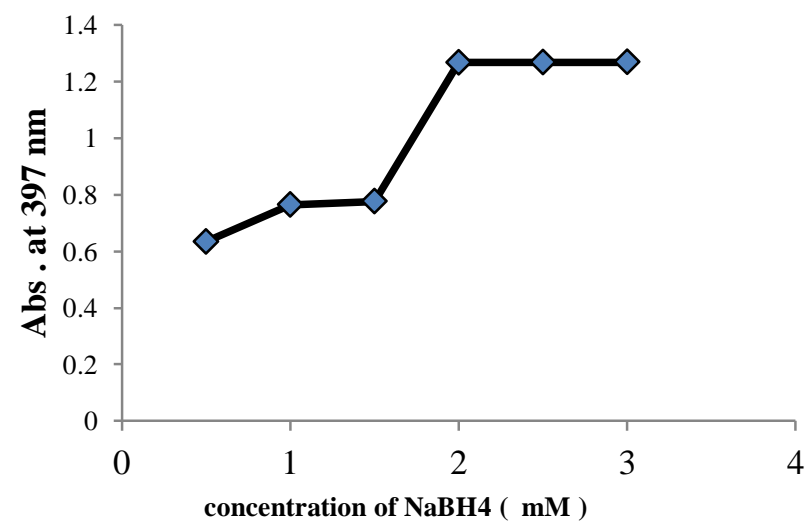

SI 3: Effect of the amount of $\mathrm{NaBH}_{4}$ on the absorption peak of AgNPs.

\section{Effect of stabilizer type and concentration}

An important issue in the preparation of metal nanoparticles is the choice of the capping agent used to protect or stabilize the nanoparticle colloidal metals from agglomeration. Size and morphologies of nanoparticles are depending significantly on capping materials. Nanoparticles stabilization is achieved according to the two basic modes: electrostatic and steric stabilization(Oliveira et al., 2005). Electrostatic stabilization is caused by the columbic repulsion between particles, caused by the electrical double layer formed by ions adsorbed at the particle surface (e. g., sodium citrate) and the corresponding counter ions. Steric stabilization is achieved because of the coordination of sterically demanding organic molecules and polymers that act as protective shields on the metallic surface (e. g., PVP). In this study, sodium citrate (which is better used in compare to PVP) was selected as the stabilizer for preventing of silver nanoparticles agglomeration as it causes coulombic repulsion between the nanoparticles and impede the nanoparticles from diffusing together(Templeton et al., 2000).

It should be noted that, the anti-agglomeration role of PVP is due to its steric effect arises from the long polyvinyl chain of this molecule. Decrease or excessive increase in the PVP concentration may cause adverse effects on the dispersion and extinction coefficient of the plasmon band of silver nanoparticles (Zhang et al., 1996). In addition, the amid groups of PVP may cause a change in the free electron density of AgNPs and thus induce a decrease in the extinction coefficient of plasmon band (Carotenuto et al., 2000).

In this study, solutions of nanoparticles with various concentrations of citrate were examined. The maximum absorbance of AgNPs at $397 \mathrm{~nm}$ was reached by using $1.25 \%$ sodium citrate solution. Further increase in the percentage of citrate solution did not affect the absorbance (supplementary data, SI 4). Thus the preparation of AgNPs was carried out using this amount of sodium citrate solution.

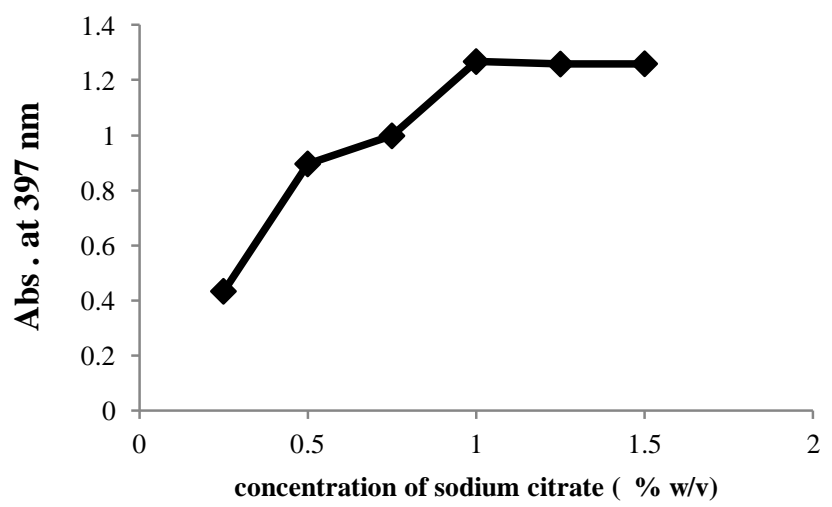

SI 4: Effect of the amount of sodium citrate solution on the absorption peak of AgNPs.

\section{Effect of reaction and standing times}

The reaction time of the proposed method was determined by monitoring the SPR absorbance as a function of time, after the colloidal solution was mixed with fluoroquinolone. The SPR absorbance reached a stable maximum within 5 min after the mixing reagents and no significant changes were observed up to $60 \mathrm{~min}$ (supplementary data, SI 5). So, the SPR absorbance of all samples was recorded $5 \mathrm{~min}$ after preparation of the solutions.

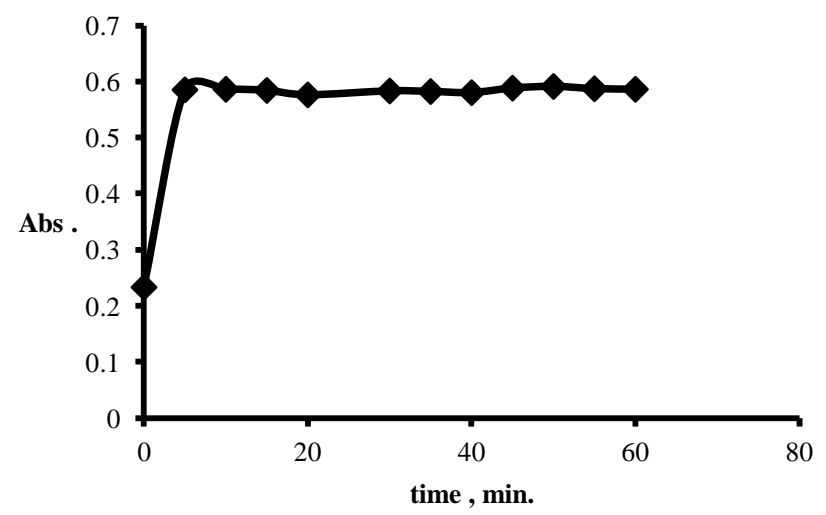

SI 5: Effect of reaction time on the SPR absorbance of the corresponding reaction. Condition: $1 \mathrm{ml}$ of AgNPs $(0.25 \mathrm{mM}), 1 \mathrm{ml}$ of $7 \mu \mathrm{g} / \mathrm{ml}$ Moxifloxacin (as an example) and $1 \mathrm{ml}$ of Toerell \& Stenhagen buffer solutions $\mathrm{pH} 8$. 
Validation of the proposed methods

The developed procedure was fully validated according to International Conference on Harmonisation guidelines (Branch 2005) in respect to linearity, range, accuracy, precision.

\section{Linearity and range}

Under the described experimental conditions, standard calibration curves for the determination of investigated fluoroquinolones with proposed AgNPs method were constructed by plotting absorbance against concentration. Linear relationships with correlation coefficients in the range of 0.9973-0.9991 were obtained. The linear concentration ranges were $1.50-10.25,2.0$ $10.25,2.0-10.50,2.0-10.50,1.5-10.0$ and $2.0-11.0 \mu \mathrm{g} / \mathrm{mL}$ for Ciprofloxacin, Ofloxacin, Levofloxacin, Moxifloxacin, Lomefloxacin and Pefloxacin, respectively. Other statistical parameters such as; correlation coefficients, intercepts, slopes detection and quantification limits are listed in (Table 1).

\section{Accuracy and Precision}

The accuracy of the method was checked by applying the general analytical procedure for the determination of the investigated drugs in three replicates at three different concentrations. The results obtained (Table 2) showed the close agreement between the measured and true values as the values of the $\%$ recovery is close to $100 \%$.

In addition, the low values of standard deviations indicated the good precision of the proposed method. The repeatability (intra-day precision) of the proposed method was checked through performing replicate analysis of the drug in pure form on three successive times. While intermediate precision (inter-day precision) was performed through repeated analysis, using the same concentration level in three successive days. The results are summarized in (Table 3) which show low values of relative standard deviations (not exceed 2\%). This gives an indication of the high precision of the proposed method.

\section{Selectivity and effect of Interferences}

In order to evaluate of the selectivity of the proposed method for the analysis of pharmaceutical preparations containing the selected fluoroquinolones, the interferences effect of various pharmaceutical additives such as glucose, lactose, fructose, maltose, sucrose and magnesium stearate was studied. Solutions containing Pefloxacin $(7.0 \mu \mathrm{g} / \mathrm{mL})$ as a representative example in the presence of one of the pharmaceutical additives $(20 \mu \mathrm{g} / \mathrm{mL})$ were analyzed with the proposed method. It was found that there was no significant interferences effect was observed by the studied excipients on the results of the method (Supplementary data, SI 5).

\section{Quantitation and detection limits}

Sensitivity of the proposed method was checked by calculating the detection (LOD) and quantitation (LOQ) limits using the formula; $\mathrm{LOD}=3.3 \mathrm{xSa} / \mathrm{b}$ and $\mathrm{LOQ}=10 \mathrm{xSa} / \mathrm{b}$, where $\mathrm{Sa}$ is the standard deviation of blank and $b$ is the slope of the calibration curve. The calculate LOD values were in the range of $0.25-0.44$ $\mu \mathrm{g} / \mathrm{mL}$ while LOQ values are in the range $0.75-1.31 \mu \mathrm{g} / \mathrm{mL}$ of the studied drugs (Table 1). This confirm the enhanced sensitivity of the suggested procedure compared to the previously reported spectrophotometric methods.

Table 1: Analytical parameters for determination of the investigated drugs by the proposed method.

\begin{tabular}{|c|c|c|c|c|c|c|c|}
\hline Drug & $\lambda_{\max }(\mathbf{n m})$ & Linear range $^{a}$ & Slope & Intercept & $\mathbf{r}^{b}$ & $\mathbf{L O D}^{\#}$ & $\mathrm{LOQ}^{\#}$ \\
\hline Ciprofloxcin & 648 & $1.75-10.25$ & 0.071 & 0.005 & 0.9978 & 0.35 & 1.04 \\
\hline Ofloxacin & 598 & $2.00-10.25$ & 0.093 & 0.082 & 0.9974 & 0.42 & 1.26 \\
\hline Levofloxacin & 598 & $2.00-10.50$ & 0.095 & 0.066 & 0.9973 & 0.44 & 1.31 \\
\hline Moxifloxacin & 630 & $2.00-10.50$ & 0.101 & 0.037 & 0.9991 & 0.25 & 0.75 \\
\hline Lomefloxacin & 648 & $1.50-10.00$ & 0.082 & 0.008 & 0.9980 & 0.37 & 1.10 \\
\hline Pefloxacin & 696 & $2.00-11.00$ & 0.072 & 0.013 & 0.9984 & 0.34 & 1.02 \\
\hline
\end{tabular}

${ }^{\text {a }}$ The concentration is in $\mu \mathrm{g} / \mathrm{ml}$.

${ }^{\mathrm{b}}$ LOD; limit of detection, LOQ; limit of quantitation, and r; correlation coefficient.

Table 2: Evaluation of accuracy of the analytical procedure of the studied drugs.

\begin{tabular}{|c|c|c|c|c|}
\hline \multirow[t]{2}{*}{ Drugs } & \multicolumn{4}{|c|}{$\%$ Recovery $^{a}$} \\
\hline & $4.00 \mu \mathrm{g} / \mathrm{mL}$ & $6.00 \mu \mathrm{g} / \mathrm{mL}$ & $8.00 \mu \mathrm{g} / \mathrm{mL}$ & Mean \pm SD $^{\#}$ \\
\hline Ciprofloxacin & 98.32 & 98.73 & 101.25 & $98.40 \pm 1.60$ \\
\hline Ofloxacin & 101.39 & 98.67 & 99.26 & $99.77 \pm 1.43$ \\
\hline Pefloxacin & 100.38 & 102.01 & 98.32 & $100.24 \pm 1.85$ \\
\hline Levofloxacin & 99.02 & 101.79 & 100.25 & $99.50 \pm 1.39$ \\
\hline Moxifloxacin & 102.86 & 100.41 & 99.34 & $100.89 \pm 1.80$ \\
\hline Lomefloxacin & 96.96 & 98.93 & 99.53 & $98.47 \pm 1.34$ \\
\hline
\end{tabular}

a Average of three determinations, \# SD Standard deviation.

Table 3: Evaluation of intra- and inter-day precision of the analytical procedure of the studied drugs $(6.0 \mu \mathrm{g} / \mathrm{mL})$.

\begin{tabular}{|c|c|c|}
\hline \multirow[t]{2}{*}{ Drug } & \multicolumn{2}{|c|}{$\%$ Recovery $^{*} \pm$ RSD $^{a}$} \\
\hline & Intra-day precision & Inter-day precision \\
\hline Ciprofloxacin & $99.76 \pm 1.76$ & $99.45 \pm 0.73$ \\
\hline Ofloxacin & $100.30 \pm 0.61$ & $99.14 \pm 1.42$ \\
\hline Lomefloxacin & $100.08 \pm 0.58$ & $100.01 \pm 0.49$ \\
\hline Levofloxacin & $99.98 \pm 1.08$ & $100.58 \pm 0.81$ \\
\hline Moxifloxacin & $100.58 \pm 0.81$ & $99.99 \pm 0.21$ \\
\hline Pefloxacin & $100.78 \pm 1.12$ & $99.73 \pm 1.69$ \\
\hline
\end{tabular}

$\overline{\mathrm{a}}$ Average of three determinations, RSD is Relative standard deviation. 
Table 4: Analysis of the studied fluoroquinolones in its pharmaceutical formulations using the proposed and reported methods.

\begin{tabular}{|c|c|c|c|c|c|}
\hline \multirow[t]{2}{*}{ Dosage forms } & \multirow{2}{*}{$\begin{array}{c}\text { Drug } \\
\text { (conc.) }\end{array}$} & \multicolumn{2}{|c|}{$\%$ Recovery $^{\mathrm{a}} \pm \mathrm{SD}$} & \multirow[t]{2}{*}{ t-test } & \multirow[t]{2}{*}{ F-value } \\
\hline & & Proposed method & Reported method & & \\
\hline Ciprocin eye drop & Ciprofloxacin $(3 \mathrm{mg} / 1 \mathrm{ml})$ & $100.86 \pm 1.53$ & $99.43 \pm 1.10[32]$ & 1.32 & 1.93 \\
\hline Ofloxin eye drop & Ofloxacin $(3 \mathrm{mg} / 1 \mathrm{ml})$ & $101.38 \pm 0.56$ & $100.51 \pm 0.67$ & 0.53 & 2.71 \\
\hline Lee-flox eye drop & Levofloxacin $(5 \mathrm{mg} / 1 \mathrm{ml})$ & $101.00 \pm 0.83$ & $100.33 \pm 1.10$ & 0.84 & 1.76 \\
\hline Ciprofloxacin injection (I.V) & Ciprofloxacin $(200 \mathrm{mg} / 100 \mathrm{ml})$. & $100.25 \pm 0.82$ & $100.11 \pm 0.72$ & 0.23 & 1.30 \\
\hline Venaxan injection (I.V) & Levofloxacin $(500 \mathrm{mg} / 100 \mathrm{ml})$ & $100.95 \pm 1.06$ & $100.02 \pm 1.34$ & 0.94 & 1.60 \\
\hline Maxa-flox eye drop & Lomefloxacin (3 mg/1 ml ) & $99.47 \pm 1.09$ & $99.97 \pm 1.55[33]$ & 0.46 & 2.02 \\
\hline Vigamox eye drop & Moxifloxacin (3 mg/1 ml) & $99.45 \pm 0.73$ & $100.94 \pm 1.07[34]$ & 1.99 & 2.15 \\
\hline
\end{tabular}

${ }^{\mathrm{a}}$ Theoretical value at $95 \%$ confidence limit; $\mathrm{F}=3.18$ and $\mathrm{T}=2.78$.

SI 6: Effect of presence of commonly used excipients on the determination of Pefloxacin $(7.0 \mu \mathrm{g} / \mathrm{mL})$ as representative example.

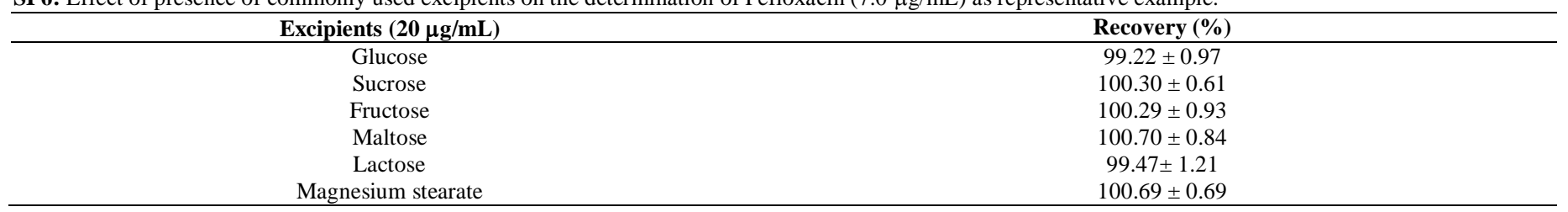

\section{Application to pharmaceutical dosage forms}

Finally, the proposed method has been applied in determining the studied drugs in commercial tablets, eye drops and I.V Infusion. The results were compared statistically with those of the reported methods using student's t- and F- tests at the 95\% confidence level (Table 4).

The absence of any significant difference between the calculated and theoretical values of both t- and F-values indicated good levels of accuracy and precision of the proposed method, respectively. The sensitivity, simplicity and minimal volume of samples make the method suitable for routine analysis in quality control laboratories.

\section{CONCLUSION}

In this work, we described the use of citrate-capped AgNPs as colorimetric probe for determination of six fluoroquinolone drugs (Ciprofloxacin, Lomefloxacin, Ofloxacin, Pefloxacin, Levofloxacin and Moxifloxacin).

The binding action between the ligands of citrate capped $\mathrm{Ag}$ NPs and fluoroquinolone drugs led to significant red-shift in the absorption spectra with concomitant visible color changes from yellow to blue. The method offers several advantages over the previously reported analytical techniques for the studied drugs.

From economic point of view, the proposed method is simple, rapid and inexpensive as it is less time-consuming and does not require various elaborate treatment or tedious extraction procedures. From environmental point of view, the proposed method is environmentally safe since water is the reaction solvent which is the most important green solvent and volatile solvents are omitted in the present work. Additionally, the method was successfully validated to quantify the fluoroquinolone drugs in pharmaceutical preparations. It could be concluded that this approach has great potentiality for the detection of studied fluoroquinolones in pharmaceutical samples with high accuracy and precision.

\section{Financial support and sponsorship: Nil.}

Conflict of Interests: There are no conflicts of interest.

\section{REFERENCES}

Abdel-Gawad FM, Issa YM, Fahmy HM, Hussein HM. Spectrophotometric determination of ciprofloxacin in pure form and in tablets through charge-transfer complexation reactions. Microchimica Acta, 1998; 130:35-40.

Al - Momani I. Flow injection spectrophotometric determination of the antibacterial levofloxacin in tablets and human urine. Analytical letters, 2006; 39:741-750.

Avsec H, Gomišček S. A study of the prospects for a ciprofloxacin PVC coated wire ion-selective electrode based on 4quinolones. Analytica chimica acta, 1992; 268:307-309.

Ayad M, Abdellatef H, Hosny M, Kabil N. Utility of molybdophosphoric acid in qualitative and quantitative analysis of Sibutramine $\mathrm{HCl}$, Sumatribtan succinate and Lomefloxacine HCl. Int. J. Pharm. Biomed. Res, 2012; 3:121-126.

Basavaiah K, Prameela H. Sensitive spectrophotometric method for the determination of pefloxacin. Indian journal of chemical technology, 2002; 9:428-431.

Basu S, Ghosh SK, Kundu S, Panigrahi S, Praharaj S, Pande S, Jana S, Pal T. Biomolecule induced nanoparticle aggregation: effect of particle size on interparticle coupling. Journal of colloid and interface science, 2007; 313:724-734.

Belal F, El-Din MS. Polarographic behavior and determination of Flumequine. Microchemical journal, 1990; 42:300-305.

Branch SK. Guidelines from the international conference on harmonisation $(\mathrm{ICH})$. Journal of pharmaceutical and biomedical analysis, $2005 ; 38: 798-805$.

Carotenuto G, Pepe G, Nicolais L. Preparation and characterization of nano-sized Ag/PVP composites for optical applications. The European Physical Journal B-Condensed Matter and Complex Systems, 2000; 16:11-17.

El-Brashy AM, Metwally ME-S, El-Sepai FA. Spectrophotometric determination of some fluoroquinolone antibacterials through charge-transfer and ion-pair complexation reactions. Bulletin of the Korean Chemical Society, 2004; 25:365-372. 
El-Hawary W, Al-Gethami FK. Mutual spectrophotometric determination of Moxifloxacin drug and iron (III) ions by formation of a complex compound. European Chemical Bulletin, 2012; 2:22-27.

El-Kommos ME, Saleh GA, El-Gizawi SM, Abou-Elwafa MA. Spectrofluorometric determination of certain quinolone antibacterials using metal chelation. Talanta, 2003; 60:1033-1050.

El - Brashy AM, Metwally MES, El - Sepai FA. Spectrophotometric Determination of Some Fluoroquinolone Antibacterials by Ion - pair Complex Formation with Cobalt (II) Tetrathiocyanate. Journal of the Chinese Chemical Society, 2005; 52:7784.

Evanoff DD, Chumanov G. Size-controlled synthesis of nanoparticles. 2. Measurement of extinction, scattering, and absorption cross sections. The Journal of Physical Chemistry B, 2004; 108:1395713962.

Fierens C, Hillaert S, Van den Bossche W. The qualitative and quantitative determination of quinolones of first and second generation by capillary electrophoresis. Journal of pharmaceutical and biomedical analysis, 2000; 22:763-772.

Fratini L, Schapoval EE. Ciprofloxacin determination by visible light spectrophotometry using iron (III) nitrate. International journal of pharmaceutics, 1996; 127:279-282.

González JO, Mochón MC, de la Rosa FB. Simultaneous determination of cefepime and the quinolones garenoxacin, moxifloxacin and levofloxacin in human urine by HPLC-UV. Microchimica Acta, 2005; $151: 39-45$.

Guo J-Z, Cui H, Zhou W, Wang W. Ag nanoparticle-catalyzed chemiluminescent reaction between luminol and hydrogen peroxide. Journal of Photochemistry and Photobiology A: Chemistry, 2008; 193:8996.

Gupta H, Aqil M, Khar R, Ali A, Chander P. A single reversedphase UPLC method for quantification of levofloxacin in aqueous humour and pharmaceutical dosage forms. Journal of chromatographic science, 2010; 48:484-490

Hooper D, Wolfson J. Mechanisms of quinolone action and bacterial killing. Quinolone antimicrobial agents, 1993; 2:53-76.

Jain DK, Patel P, Chandel HS, Kushwaha A, Jain N. Development and validation of reversed phase- high-performance liquid chromatography method for determination of paracetamol and lornoxicam in tablet dosage form. Pharmaceutical Methods, 2011; 2:42-46.

Jain PK, Huang X, El-Sayed IH, El-Sayed MA. Noble metals on the nanoscale: optical and photothermal properties and some applications in imaging, sensing, biology, and medicine. Accounts of chemical research, 2008; 41:1578-1586.

Jelikić-Stankov M, Stankov D, Djurdjević P. Determination of pefloxacin in serum by time-resolved fluorimetry. Die Pharmazie, 1999; $54: 73$.

Kaur K, Kumar A, Malik AK, Singh B, Rao A. Spectrophotometric methods for the determination of fluoroquinolones: a review. Critical Reviews in Analytical Chemistry, 2008; 38:2-18.

Kaur K, Singh B, Malik AK. Micelle enhanced spectrofluorimetric method for the determination of ofloxacin and lomefloxacin in human urine and serum. Thai J. Pharm. Sci, 2010; 34:58 66.

Kiliç E, Koseoglu F, Akayt MA. The non-aqueous titrimetric assay of selected antibiotics using tetra-N-butylammonium hydroxide as titrant. Journal of pharmaceutical and biomedical analysis, 1994; 12:347352.

Laliwala SK, Mehta VN, Rohit JV, Kailasa SK. Citratemodified silver nanoparticles as a colorimetric probe for simultaneous detection of four triptan-family drugs. Sensors and Actuators B: Chemical, 2014; 197:254-263.

Lee P, Meisel D. Adsorption and surface-enhanced Raman of dyes on silver and gold sols. The Journal of Physical Chemistry, 1982; 86:3391-3395.
Mandell GL, Bennett JE, Dolin R. Book Reviews-Mandell, Douglas and Bennett's Principles and Practice of Infectious Diseases. Clinical Infectious Diseases, 2000; 31:1281.

Merga G, Wilson R, Lynn G, Milosavljevic BH, Meisel D. Redox catalysis on "naked" silver nanoparticles. The Journal of Physical Chemistry C, 2007; 111:12220-12226.

Navalón A, Ballesteros O, Blanc R, Vílchez JL. Determination of ciprofloxacin in human urine and serum samples by solid-phase spectrofluorimetry. Talanta, 2000; 52:845-852.

Ni Y, Wang Y, Kokot S. Simultaneous determination of three fluoroquinolones by linear sweep stripping voltammetry with the aid of chemometrics. Talanta, 2006; 69:216-225.

Oliveira MM, Ugarte D, Zanchet D, Zarbin AJ. Influence of synthetic parameters on the size, structure, and stability of dodecanethiolstabilized silver nanoparticles. Journal of colloid and interface science, 2005; 292:429-435.

Parent X, Marchal A, Patillon J (2004). Corneal precipitation of fluoroquinolones with magnesium. Annales de biologie clinique.

Patel GM, Rohit JV, Singhal RK, Kailasa SK. Recognition of carbendazim fungicide in environmental samples by using 4aminobenzenethiol functionalized silver nanoparticles as a colorimetric sensor. Sensors and Actuators B: Chemical, 2015; 206:684-691.

Pharmacopoeia B. London. England: Her Majesty's Stationary Office, 1998.

Pharmacopoeia CotEoaE. 1998. European Pharmacopoeia: Supplement: Council of Europe.

Qu J-c, Chang Y-p, Ma Y-h, Zheng J-m, Li H-h, Ou Q-q, Ren $\mathrm{C}$, Chen X-g. A simple and sensitive colorimetric method for the determination of propafenone by silver nanoprobe. Sensors and Actuators B: Chemical, 2012; 174:133-139.

Rajasekaran A, Jaykar B, Dhanalakshmi S, Deepalakshmi M, Beulah VI. Visible Spectrophotometric Method for the Determination of Lomefloxacin Hydrochloride in Pharmaceutical Preparations. Indian journal of pharmaceutical sciences, 1998; 60:236-237.

Ravindran A, Chandran P, Khan SS. Biofunctionalized silver nanoparticles: advances and prospects. Colloids and Surfaces B: Biointerfaces, 2013; 105:342-352.

Rizk M, Belal F, Ibrahim F, Ahmed S, El-Enany N. Spectrofluorimetric analysis of certain 4-quinolone in pharmaceuticals and biological fluids. Pharmaceutica Acta Helvetiae, 2000; 74:371-377.

Rockville M (2000). The "Unitesd States Pharmocopoeia". XXIV, National Formulary, XIX, US Pharmacopoeial Convention, Inc.

Sakai M, Hara A, Anjo S, Nakamura M. Comparison of the complexation of fluoroquinolone antimicrobials with metal ions by nuclear magnetic resonance spectroscopy. Journal of pharmaceutical and biomedical analysis, 1999; 18:1057-1067.

Salem H. Spectrofluorimetric, atomic absorption spectrometric and spectrophotometric determination of some fluoroquinolones. American Journal of Applied Sciences, 2005; 2:719-729.

Schenck FJ, Callery PS. Chromatographic methods of analysis of antibiotics in milk. Journal of Chromatography A, 1998; 812:99-109.

Shah J, Jan MR, Ullah I, Shah S. Sensitive Spectrofluorimetric Method for Determination of Fluoroquinolones through Charge-Transfer Complex Formation. American Journal of Analytical Chemistry, 2013; $4: 521$.

Siddiqui FA, Arayne MS, Sultana N, Mirza AZ, Qureshi F, Zuberi MH. Facile and manifest spectrophotometric methods for the determination of six quinolone antibiotics in pharmaceutical formulations using iron salts. Medicinal chemistry research, 2010; 19:1259-1272.

Sousa J, Alves G, Fortuna A, Falcão A. Analytical methods for determination of new fluoroquinolones in biological matrices and pharmaceutical formulations by liquid chromatography: a review. Analytical and bioanalytical chemistry, 2012; 403:93-129.

Sultan MA. New, simple and validated kinetics spectrophotometric method for determination of moxifloxacine in its pharmaceutical formulations. Arabian Journal of Chemistry, 2009; 2:7985 . 
Tamer A. Adsorptive stripping voltammetric determination of ofloxacin. Analytica chimica acta, 1990; 231:129-131.

Tarkase KN, Admane SS, Sonkhede NG, Shejwal SR. Development and validation of UV-spectrophotometric methods for determination of moxifloxacin $\mathrm{HCl}$ in bulk and pharmaceutical formulations. Der Pharma Chemica, 2012; 4:1180-1185.

Templeton AC, Wuelfing WP, Murray RW. Monolayerprotected cluster molecules. Accounts of chemical research, 2000; 33:2736.

Thompson DG, Enright A, Faulds K, Smith WE, Graham D. Ultrasensitive DNA detection using oligonucleotide-silver nanoparticle conjugates. Analytical chemistry, 2008; 80:2805-2810.

Vilela D, González MC, Escarpa A. Sensing colorimetric approaches based on gold and silver nanoparticles aggregation: Chemical creativity behind the assay. A review. Analytica chimica acta, 2012; 751:24-43.

Wang P-L, Feng Y-L, Chen L. Simultaneous Determination of Trace norfloxacin, pefloxacin, and ciprofloxacin by TLC-Fluorescence Spectrodensitometry. Microchemical journal, 1997; 56:229-235.

Willets KA, Van Duyne RP. Localized surface plasmon resonance spectroscopy and sensing. Annu. Rev. Phys. Chem., 2007; 58:267-297.

Xiong D, Chen M, Li H. Synthesis of para-sulfonatocalix [4] arene-modified silver nanoparticles as colorimetric histidine probes. Chemical Communications, 2008:880-882.
Xiong D, Li H. Colorimetric detection of pesticides based on calixarene modified silver nanoparticles in water. Nanotechnology, 2008; 19:465502.

Zhang S, Sun Z, Sun X. Determination of ciprofloxacin lactate in injections by acid dye biphasic titration. Yaowu Fenxi Zazhi, 1996; $16: 402$.

Zhang Z, Zhao B, Hu L. PVP protective mechanism of ultrafine silver powder synthesized by chemical reduction processes. Journal of Solid State Chemistry, 1996; 121:105-110.

\section{How to cite this article:}

Derayea SM, Omar MA, Hammad MA, Hassan YF. Application of surface plasmon resonance of citrate capped silver nanoparticles for the selective determination of some fluoroquinolone drugs. J App Pharm Sci, 2017; 7 (02): 016-024. 